University for Business and Technology in Kosovo

UBT Knowledge Center

UBT International Conference

2014 UBT International Conference

Nov 7th, 2:30 PM - 2:45 PM

\title{
Documentation and Inventory of Architectural Heritage.The European model including the role of universities within
}

Caroline Jaeger Klein

Vienna University of Technology, jaeger-klein@tuwien.ac.at

Follow this and additional works at: https://knowledgecenter.ubt-uni.net/conference

Part of the Architecture Commons

\section{Recommended Citation}

Klein, Caroline Jaeger, "Documentation and Inventory of Architectural Heritage. The European model including the role of universities within" (2014). UBT International Conference. 16.

https://knowledgecenter.ubt-uni.net/conference/2014/all-events/16

This Event is brought to you for free and open access by the Publication and Journals at UBT Knowledge Center. It has been accepted for inclusion in UBT International Conference by an authorized administrator of UBT Knowledge Center. For more information, please contact knowledge.center@ubt-uni.net. 


\title{
Documentation and Inventory of Architectural Heritage.The European model including the role of universities within.
}

\author{
Caroline Jaeger-Klein \\ Vienna University of Technology, Department for History of Architecture and Building \\ Archaeology, Vienna, Austria \\ jaeger-klein@,tuwien.ac.at
}

\begin{abstract}
Preserving its architectural heritage has a long tradition in the European history. For the famous Renaissance and Baroque architects especially in Italy it was considered to be integrated part of their "art". Hence, it were art historians to start systematic documentation of the cultural heritage around 1900. For Central Europe Georg Dehio in Strasbourg and Alois Riegl and Max Dvořák in Vienna were most influential. Their legacy are printed inventory handbooks and art-topographies, which documented the built heritage and gave public access to heritage information. This is the inevitable base for protection and care of monuments as well as for rehabilitation and adaptive reuse, and last but not least cultural tourism. It is high time for Kosovo to start a similar systemic inventory. European expertise has already developed various methods for different heritage categories - from sacral single monuments to representative domestic architecture, from ensembles to vernacular architecture and most recent for industrial heritage, in the meantime hotspot of the private real estate market for re-development. Nevertheless, documentation and inventory is of public interest, if we really intend to save our heritage seriously. Therefore the involvement of neutral institutions, like universities, is inevitable and a long-term investment on both sides. The students gain expertise during their academic education, learning by doing on the site and experiencing the knowledge of their grandfathers by accurate observation and serious analysis. Only the ones who experienced the traditions will be able to build the future. If you have a strategic program for all universities of a certain region, you quickly gain information on the valuable building stock: Reports on the development of the structure, detailed sketches and drawings in scale, full sets of technical plans as result of detailed measurement give information on material, construction and space distribution. The reports are base for evaluation and protection, the measurements base for care, repair and adaption to contemporary use. A central architectural heritage database has to be accessible for everyone.
\end{abstract}

Keywords: Architectural Heritage, Handbooks of Inventory, Topography of Art, Systemic Documentation

\section{Introduction}

"Most frequently two tasks are named which the art topographies asides their determination as means of the public protection of monuments: to awake public interest in old monuments and to research and publish them scientifically." Am häufigsten werden zwei Aufgaben genannt, welche die Kunsttopographien neben ihrer Bestimmung als Behelf des staatlichen Denkmalschutzes erfüllen sollen: die Erweckung der öffentlichen Anteilnahme an den alten Denkmalen und ihre wissenschaftliche Erforschung und Veröffentlichung ${ }^{2}$, Max Dvořák wrote 1907 as introduction to the first volume of his Austrian Topography of Art.

Nothing essential has changed in the meantime and the Austrian Topography of Art is still edited regularly. Nevertheless, the knowledge transferred within has grown. Therefore, even Austria nowadays uses the condensed version of inventory handbooks, which Georg Dehio configured parallel to Dvořák within the first decennium of the $20^{\text {th }}$ century. The same institution edits both series, but with different

2 Cited after Huse (ed.), Denkmalpflege, 2006, p. 171. 
scopes. Hence, both were reluctant to accept the recent architectural heritage, which led to supplementing architectural guidebooks in the course of the times.

What remains an unsolved problem for the institutions in the back is the increasing number of buildings considered of value. Their personal resources have been insufficient all the times. Besides, they have to cope with the influence of lobbies who do not want public lists of valuable buildings. Finally, the authors and researchers behind the inventory books are mainly educated art historian not trained for technical survey of buildings. Therefore, the inventory books are textbooks, but with the strong wish early to embed also graphical material like site- and ground floor plans, what the art historians cannot provide.

When the European council announced for 1975 “The European Year of Monuments", Hans Koepf, professor for history of architecture at Vienna University of Technology, had already prepared a systemic survey initiative for the major towns of Austria that involved the students of architecture in the documentation of the historic building stock. The academic program and its results were exhibited at the European council in 1975 with some echo in the media.

As nowadays with the recent shifts in the political landscape especially in the Southeast of Europe and the Nearer East, many countries of that region discovered the potential of their historic national building stock for giving the new states legacy as well as identity. Within that context, systemic documentation and inventory of the traditional architectural heritage has gained stunning actuality. Therefore, the author wants to recollect and reflect on those inventory and documentation systems to hand them over as "European model".

\section{Art Topographies and Handbooks of Inventory}

\subsection{Georg Dehio and his handbooks}

Our department at Vienna University of Technology holds a full set of plans presenting the major churches of Western Europe, published 1888 in Stuttgart as "book" of several volumes, physically a collection of files, and entitled with "The Christian Art of Building within the Occident. Historically and systematically represented by Georg Dehio and Gustav von Bezold" (Die kirchliche Baukunst des Abendlandes. Historisch und systematisch dargestellt von Georg Dehio und Gustav von Bezold) Georg Dehio (1850-1932), born in Reval/Tallin, today Estonia, studied history in Gottingen and started to teach at the university and academy of art at Konigsberg, at that times a major town in Prussia (today Kaliningrad in Russia). He published this file collection of the most important sacral buildings of Europe described above, before he was advocated from Konigsberg to Strasburg (today Strasbourg), where he lead the Art Institute until 1919. There he defined parallel to two Viennese art historians, Alois Riegl und Max Dvoŕák, what today still is state of the art in protection and care of monuments - in theory as well as in practice.

Looking more closely into those plan collection and rethinking its basic system today is still astonishing. Not only that we architectural historians still use those ground plans, sections and interior elevations without doubting their accuracy in geometrical description, we got so used to their specific expression that only recently the point clouds of laser scanning occur as real novelty. Originally printed in brown color, the plans of Dehio/Bezold are technical drawings without any single numeral figure or descriptive text besides the naming of the building itself and a graphical scale.

From some pencil marks, students of our department have added over the times, we easily figure out the ideology of monument protection within the times. At Saint Sepulcre in Neuvy is marked that Viollet-le-Duc has finished the upper parts of the building. Immediately we know that the churches here are described in their restored status of the 19th century which tried to show an ideal medieval phase, which the building lost later through modernization or never had ever had reached. It brings us shockingly into mind that some iconic buildings like the cathedral of Cologne actually do not have more 
than $15 \%$ of original medieval building substance but $85 \%$ of the material is from the 19th century. Therefore, we can understand that Georg Dehio very clearly voted for "conservation, not restoration", the slogan, which made him famous when he used it in his so called "speech to the (German) emperor" in 1905. "We do not conserve a monument because it is beautiful, but because it is a piece of our national being, when protecting monuments we do not look for pleasure but for piety"3, he states clearly against the restoration habits of the times. And he already pleads for a more popularity of monument protection in knowing that only this will finally lead to sustainability, if more than the educated ones develop a certain patriotism: "In all strata of society there should be a feeling that a people in possession of many monuments is a noble people."4

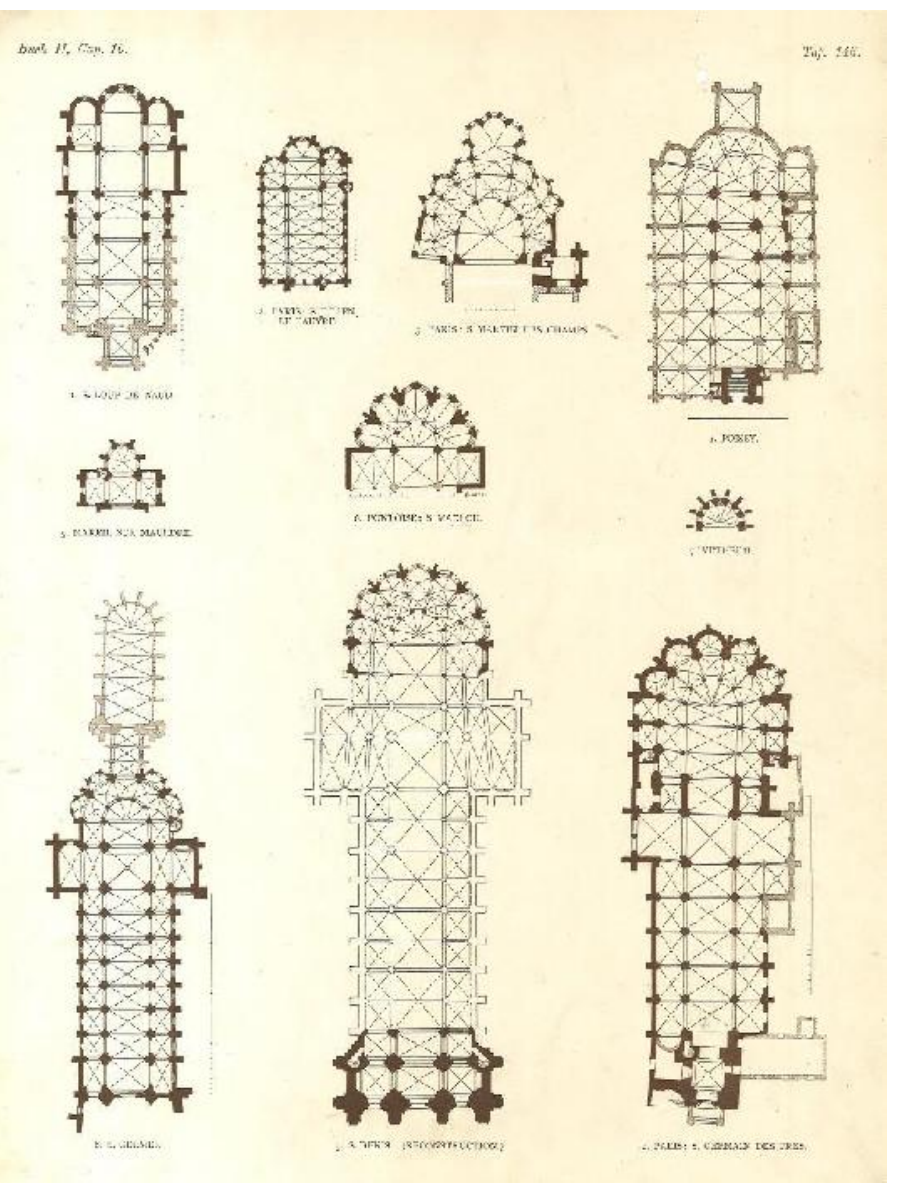

Fig. 3. One page of the 1888 publication from Georg Dehio and Georg von Bezold on the sacral architectural heritage of Europe, presenting the ground plans of the most important medieval churches of the continent. The differently shades parts of the buildings indicate their age (black - oldest) and their current condition (white - no longer existing).

In this context, we have to see the project of a "handbook containing in ordered form all the precious German monuments", which Georg Dehio already was in charge of 1905, when the first annual

${ }^{3}$ Andreas Lehne, "Georg Dehio, Alois Riegl, Max Dvořak - a threshold in theory development“, pp. 69-80, in: ICOMOS (ed.), Conservation and Preservation, 2008, p. 73.

${ }^{4}$ Ibidem. 
conference on the topic took place in Dresden ("day of monument protection"). The five volumes of his handbook published between 1905 and 1912 contain all parts of the former German Empire including German Switzerland and Elsass-Lothringen. Austria followed in 1933. Western as well as Eastern Germany relaunched the program from 1964 till1993 separately, nowadays of course united. In 1993, Poland joined the idea as well as the name. Today very often people do no longer know that Georg Dehio once was a real existing person. The "Dehio" simply became synonym for the handbook.
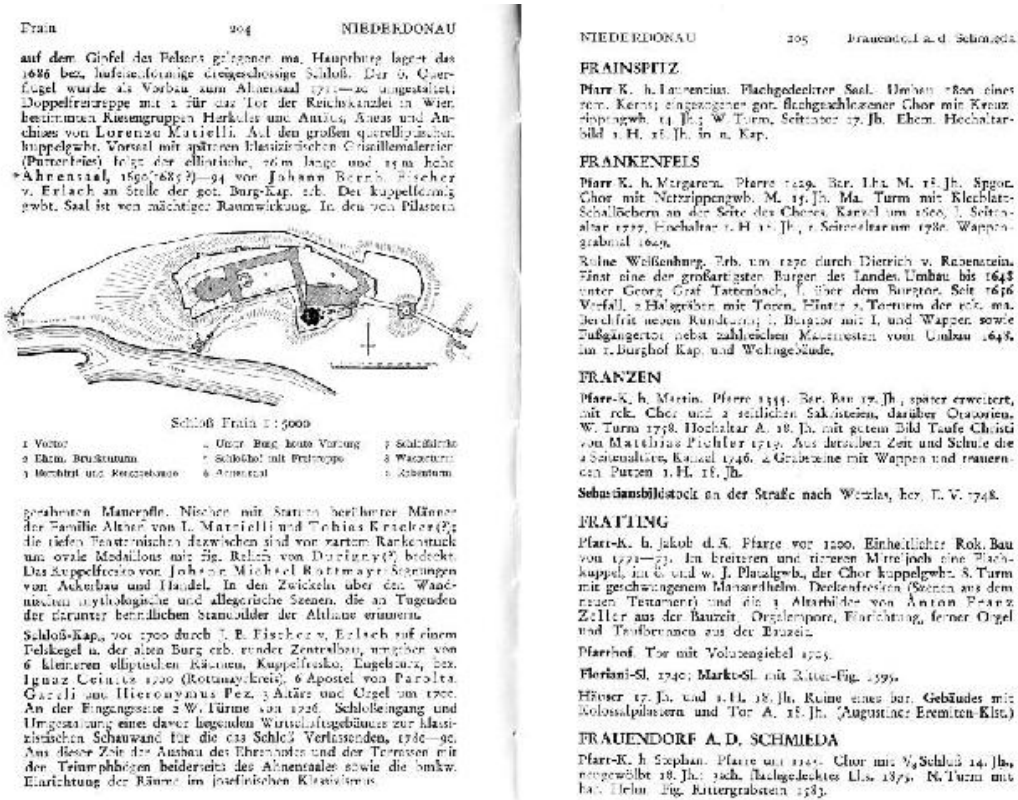

Fig. 2. The Dehio-Handbook names the political districts and the locations in alphabetical order. The books in general hold just one province per volume. They first give some general morphological information on the site, before they get into the monumental sacral and domestic buildings first, followed by the important residential buildings, sorted after street address. These pages are from a Dehio handbook published during the national-socialist "occupation" of Austria, which you recognize through the renaming of some provinces. Nevertheless, the inventory of national monuments was important for the old Austrian as well as the new German regime. Karl Ginhart, Dehio Handbuch der deutschen Kunstdenkmäler in der Ostmark. Erster Band. Wien und Niederdonau, Wien-Berlin 1941.

\subsection{The Austrian Topographies of Art}

In Austria the printed version of the handbooks can, and could always be, bought by everybody, but there is digital database behind for expert's use only. The Austrian Federal Institute for Protection and Care of Monuments is in charge of both version and Lehne cited before, head of the Department for Documentation and Inventory. In Austria, the handbooks did not start parallel with the German. Austria in contradiction to Germany very early saw the task as national effort and public duty. Already in 1853, Austria established a central commission, the k.k. Zentralkommission für Erforschung und Erhaltung der Baudenkmale, to care about monuments as well as to coordinate the research. Its publications, yearbook as well as bulletin, held the leading position within the German literature on art. At the beginning, the commission was lead in an honorary capacity. In 1911, it was declared to be a state institution but affiliated to the Institute of Art-History of the University of Vienna, which did not only edit the Yearbook of History of Architecture but also the Austrian Topography of Art. 


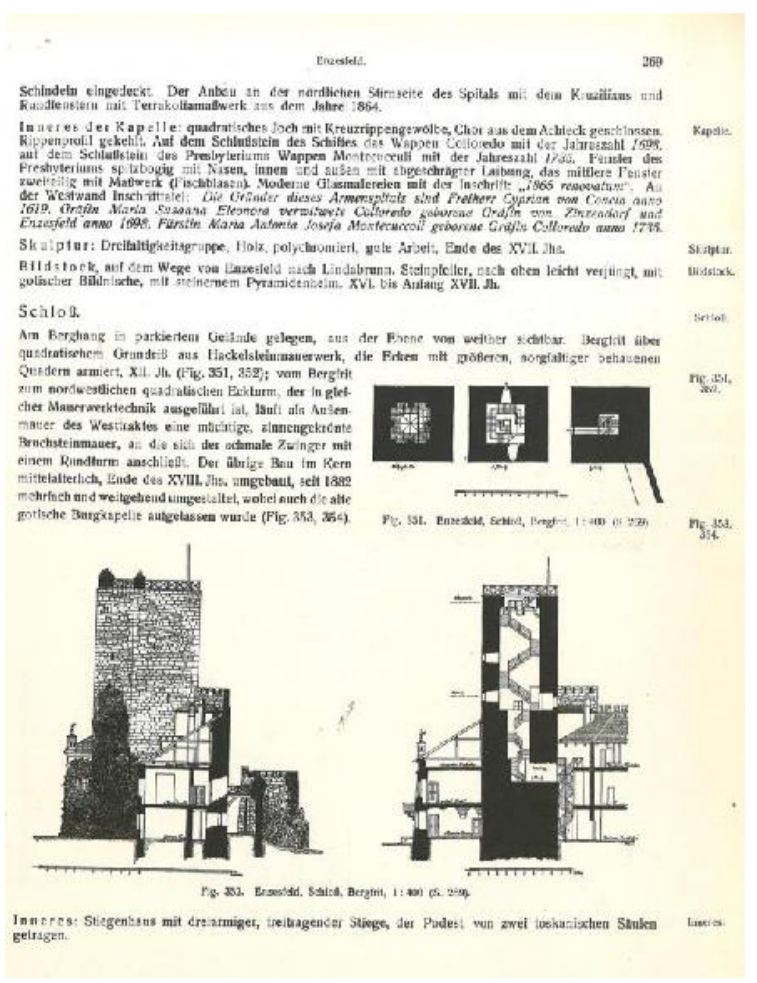

Fig. 3. The Austrian Topography of Art shows even more in detail the architectural heritage, but not only. It describes also pieces of sculpture within and outside of buildings and the emphasis is in general more on decoration and furniture. Dagobert Frey, Die Denkmale des politischen Bezirkes Baden, Band XXVIII der Österreichischen Kunsttopographie, Wien 1924.

The latter is in its systematic approach very close to the handbook of Dehio, but additionally holds prehistoric archaeological information as well as detailed information on painting and sculpture integrated into architecture. Nevertheless, also Georg Dehio's books in their origin named themselves handbook of the German Monuments of Art $^{5}$. It only explains why Dehio named criteria a little bit different as the equally influential Austrian art historians Riegl and Dvořák. Dehio as historian acted more as technician and scientist, the art historians Riegl and Dvořák as artists. For them the creation of values (memory, historic, age, art value etc.) was the claiming priority, for Dehio arguments understood by everybody and not only the expert. Hence, the goal to archive matched.

\subsection{Principles of Inventory}

Looking through the principles of inventory for the monuments of Bavaria from $1904^{6}$, we are still surprised through their actuality. The intention of inventory is to locate the full stock of monuments of a country, to describe it scientifically and therewith serve the protection and care of those monuments as well as the history of art (and architecture), the history of the country and the history of the region. This is to the benefit of the vivid (contemporary) art (and architecture) and strengthens the identity of its population (Heimatliebe).

${ }^{5}$ Compare Leixner, Einführung in die Architektur, 1919, p. 334f.

6 "Grundsätze für die Inventarisation der Kunstdenkmäler Bayerns“ (1904), in: Huse (ed.), Denkmalpflege, 2006, p. 167-171. 
In the next steps it defines the range of times (historic monuments of art and architecture), the ownership (public as well as private unmovable objects) and categories of buildings: sacral equally to profane, domestic as well as vernacular, technical buildings like bridges as well as classical artistic monuments like markings of ways or special holly locations. The inventory has to reach for completeness in the meaning of such questions: What does this object mean for the art, the architecture, the history, the archaeology? What is its value for the location, the region, the landscape, the surrounding? Everything that is contained in terms of furniture, murals, sculpture and plastic-art etc. has to be listed, further destroyed objects or parts and elements of building complexes.

In stating that inventory is not only descriptive, but also naming the references, it makes clear the fundamental seriousness of the undertaking. Responsible and autonomous analysis is the base for the work; hence, it is not intending a final and complete resume. Nevertheless, the work has to be fulfilled thoroughly and carefully.

Further principles describe the systematic of the inventory in terms of its inner organisation. This is depending largely from administrative and cultural habits and therefore has to be modified from society to society and from time to time. Nevertheless, I would like to describe the system of the European handbooks and art topographies as they have served their purpose in excellent ways for now a hundred years, and supplement some ideas for modification. The general disposition and arrangement in European inventory works the following: The location of buildings is filed under province, district and community, all in alphabetical order. For the provinces, geographical distribution might be more characteristic than alphabetical. Today, additionally the GPS-coordinates pin down exactly the location of each single building, but looking-up in reference book still works best under criteria of alphabet.

Within the communities the documented buildings are sorted under certain categories like first sacral buildings then profane buildings, divided into public (city-gates for example) and private ownership (from castles and palaces to single urban houses). The current problem is that many private, but representative buildings nowadays are in public ownership like former palaces now serving as public museums or ministries. That has to be balanced adequately if you start a current system of inventory. Domestic buildings, which have no specific names like prominent palaces normally do have, the European system sorts under their postal address in alphabetical order of the streets and a chronological numbering of the single houses. What about cultures without street names?

Another hot topic of redefinition is the question what to document: The older art topographies listed sculpture and plastic as public furnishing. Nowadays we have to add some new categories of built heritage like commercial buildings from the market to shopping malls, from bazaar institutions to caravan palaces, historic technical structures from bridges to watch tower systems, from "prehistoric" dams to cisterns have to be listed, not to forget former industrial building complexes. The latter is so extent that special handbooks of former industrial complexes in the meantime were started, under the Austrian experts in their specific language named "Dehio of industrial buildings". 


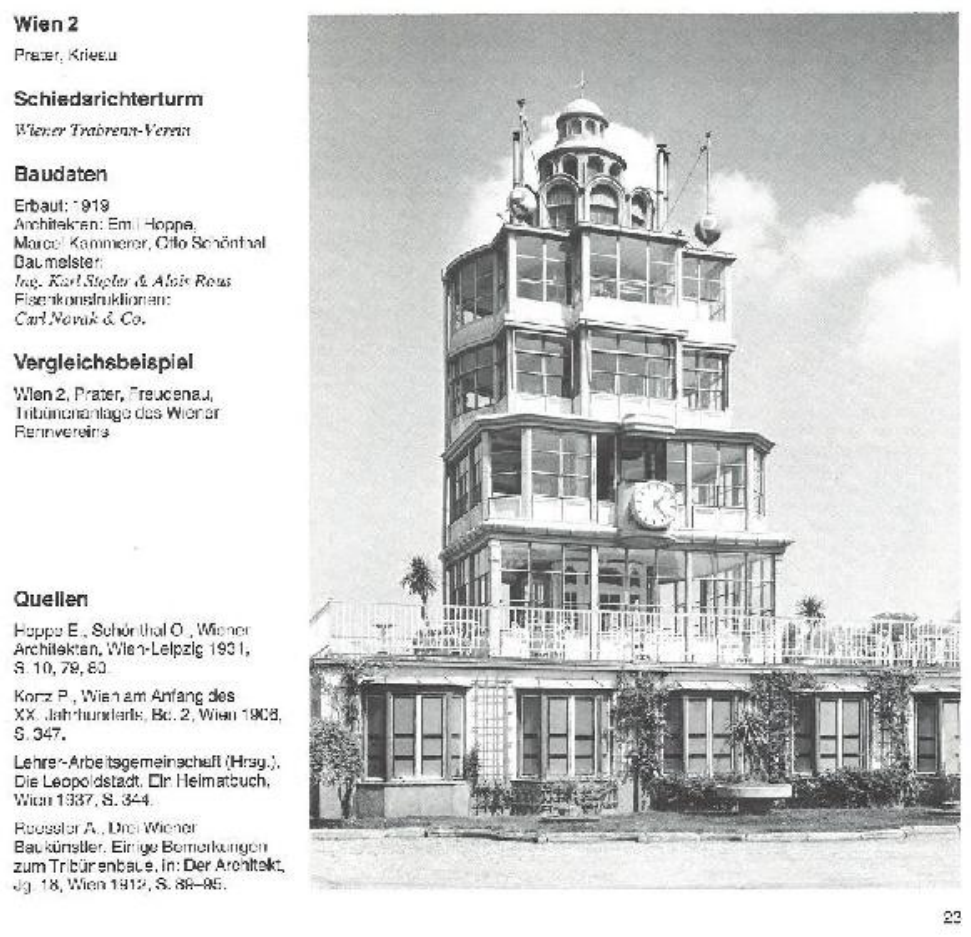

Fig. 4. Example for handbooks of industrial architecture: Manfred Wehdorn, Ute GeorgeacopolWinischhofer, Baudenkmäler der Technik und Industrie in Österreich, published in 1984. In the meantime, additionally exists a documentation of industrial heritage closer to the Topographies of Art from Gerhard A. Stadler, Das Industrielle Erbe Niederösterreichs. Geschichte-Technik-Architektur, 2006.

The description as the core of inventory cannot start out with the single building, but with some topographic specifics of the region or settlement. Those give a brief overlook in size, location, soil, resources of building material, conditions for settling like climate (temperature, humidity, major directions of air streams) and tribal affiliation, matters of trading and commerce, sacral and profane development of the territories. The system of describing each building followed in the European model the outlines, Georg von Bezold had already designed for sacral architecture. He claimed a clear division into the characteristics of the ground plan, the elevation in general, the façade in particular and some distinct features in detail. For buildings with a long time process, the mere description of the condition nowadays is complemented by its architectural development through the times, based on scientific analysis. In that context, restorations or reconstructions are mentioned including the name of the people responsible. This paragraph should be completed by a brief assessment of its art (design) and building structure (material, construction), again with giving the names of artists, architects and artisans. Additionally, specifics in the interior or decoration are described.

Extent and detail of the description are in relation to the importance of the monument. The description in general has to be clear, clearly arranged and brief in expression. She has to stress the characteristic and avoid commons as well as terms like insignificant or average. It is a specific, distinct termination developed through the European inventory, and this is an iconographic value for itself, not only as base for restoration. This is much more than mere a picture of a building, an uncommented photography or film. The person in charge of the inventory describes the little differences in plan and elevation, within the architectural details like windows, doors, profiles, etc. 
Of course, part of the description is the "style", the common architectural language, which especially the art historians got used to date buildings, but I would like to emphasize in particular that this is not sufficient. "Styles" are the definition by theory, and therefore never covering the full range of the existing - and styles are already product of inventory. If we are talking here of finding successful systems and criteria of inventory in non-European cultures, also the architectural features of those cultures have to be notices first, than described and sooner or later there the art-historians will have found their "styles". Never forget that "styles" is a means to shortcut extent descriptions but not the end in itself. Thanks to the "untraditional" categories of European monuments discovered recently, like the vernacular or industrial architecture, the traditional termination of art historians is no longer sufficient.Especially the architect and architectural critique Friedrich Achleitner, whom the nonarchitects know more as poet, formed a new language of describing and analysing the modern architecture, for which the traditional art historians vocabulary based on describing merely the ornament, no longer was sufficient. Interestingly, also for his book series, now called "guide books" to the $20^{\text {th }}$ century architecture of Austria, again the experts use the author's name for characterizing them. So, "Achleitner's" complemented the "Dehio's".A last, but very essential part of inventory is the description of the surroundings, the neighbourhood, and the context of the building structure. This means giving relative figures in contrary of absolute ones. How much is this building higher / lower than the surrounding, how much bigger in footprint? Is its silhouette in harmony to the surrounding landscape or urban shape? Are the materials unusual in this neighbourhood? Is the building serving as landmark, or are many of its type forming the mass of a quarter? This is more and more important as the idea of "cultural heritage" is more and more shifting from single monuments towards ensembles and cultural landscapes.

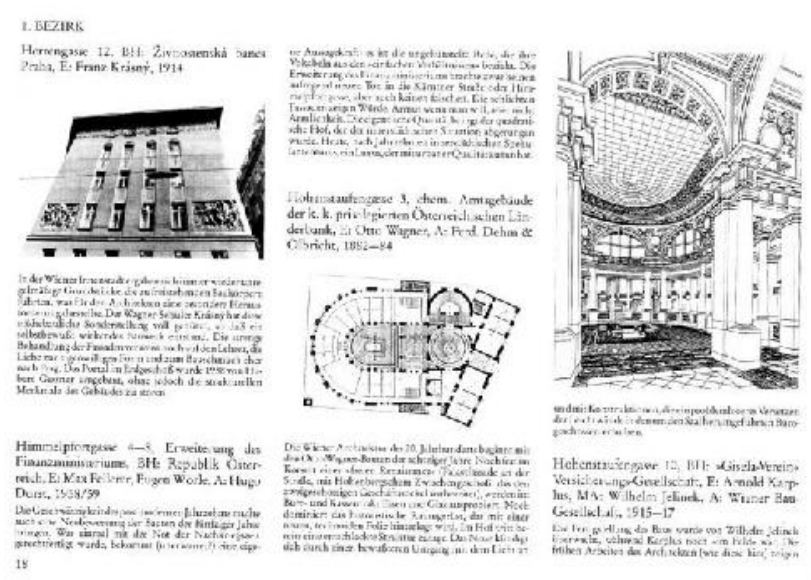

Fig. 5. The guidebooks of Friedrich Achleitner, depicting the architectural heritage of the $20^{\text {th }}$ century of Austria, use the sorting system of the Dehio handbooks, but extended them with some further building types like hospitals and school buildings. Achleitner, Österreichische Architektur im 20. Jahrhundert. Band III/1. Wien. 1.-12. Bezirk, Wien-Salzburg 1990.

\subsection{Systems and responsibilities for monument protection and inventory within Austria}

Such reflections already bring us into some other topics: Who is responsible for inventory? Who is actually carrying out the work? In 1911, restructuring of the already long-time existing central commission, the institutions for administration and research, ended in the Austrian Federal Institute for Protection and Care of Monuments (Bundesdenkmalamt - BDA).

Legislation followed a little bit later in 1923. Remember that the empire the system was developed for collapsed through World War I ending the Austrian monarchy in 1919 and leaving back a heavily cut 
state whom nearly anybody gave a chance to survive autonomously (asides Germany). It somehow proofs the values, cultural issues always have meant for my home country that even in hard times like those years after a lost war the protection and care of cultural monuments were considered to be of such essential importance to make it to public law. Until today, the Dehio handbooks do play the essential role in all law cases concerning cultural heritage.

Care and protection of monuments is a federal law, higher ranked than the building code, which differs from province to province, from county to county within the state. A sophisticated system of sponsorship is trying to balance private property and public interest in the care and protection of the 12 percent of "listed monuments" under the stock of all buildings of Austria. Clearly enough also in this matter the inventory plays the essential role of who is going to receive what specific sponsorship of public money to care about his privately owned property as public affair. Therefore, you might argue that documentation and inventory is a private issue. I would like to reply - it was wise, not to slaughter our heritage agenda to private interests so far and consider documentation and inventory of the cultural heritage as a public assignment.

Nevertheless, it cannot be provided by the state alone. Therefore the involvement of public universities is inevitable and a long-term investment on both sides. The students gain knowledge and expertise during their academic education, learning by doing on the site, experiencing the knowledge of the grandfathers by accurate observation and serious analysis. Only the ones who experienced the traditions will be able to build the future. If you have a strategic program for all the universities of a state, you quickly gain information on the valuable national building stock: reports on the development of the structures, their use within the change of times, traditional material and construction methods, detailed sketches in scale by hand, full sets of scaled plans as result of detailed measurement.

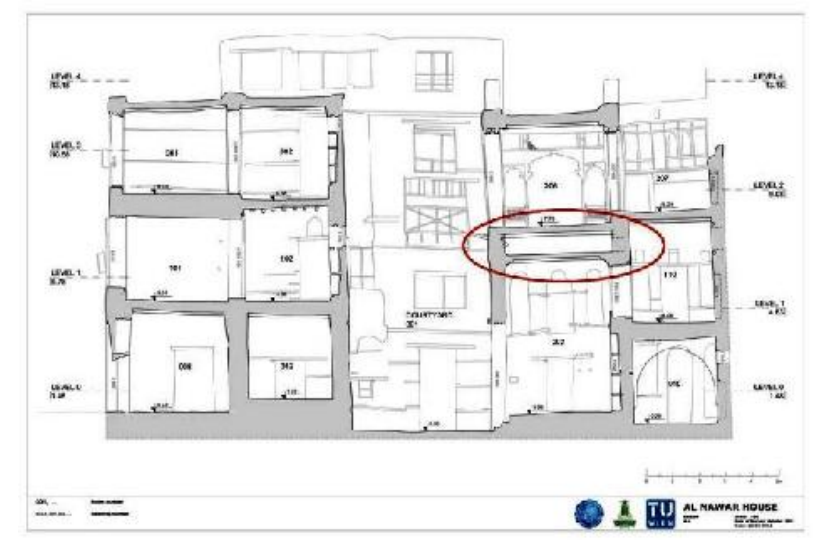

Fig. 6. Section through Al-Nawar house in Jeddah, Saudi Arabia: The building survey took place during a workshop with Saudi Arabian students of architecture, landscape architecture and geo-informatics under supervision and guidance of Austrian university teachers from Vienna University of Technology. Austrian students assisted by their teachers did the final processing of the technical plans and the analysis. This contour accurate set of plans was base for a design project to rehabilitate the house. With courtesy of Irmengard Mayer and Gudrun Styhler-Aydin, Vienna University of Technology.

The reports are base for evaluation and protection, the measurements base for care, repair and adaption to contemporary use. An independent state institution like the BDA in Austria has to coordinated and administrated. The universities are encouraged to cooperate.

The question will occur - which students, which subjects, which faculties. It is certainly a program not only for architectural students. In Austria it never has been. Clearly enough from what we have heard 
before at the beginnings students of history of art had been the ones who got and needed the training in inventory. Still today, the BDA clerks in majority are art historians. Hence, recently the architects are incredibly taking command within the institution. The reason for is many fold and still an ongoing process. We already listed and described the traditional monuments, but the inventory for non-classical categories of heritage is still missing. For technical buildings, you do need specific knowledge on function and the structural value of the building as well as in social history. In general, the ornament is no longer base of the value of $20^{\text {th }}$ century, but function or construction. Therefore, you do need an architectural education, closer to the engineer than to the artist. In the meantime, documentation and inventory has shifted to more sophisticated technical tools and equipment. Hence, the measurement of the historic buildings and the drawing of the plans, elevations and sections architects always dominated in cooperation with geodesy. My institute at the Vienna University of Technology has adopted the methods of geodesy for the use of architects to document historic building structures.

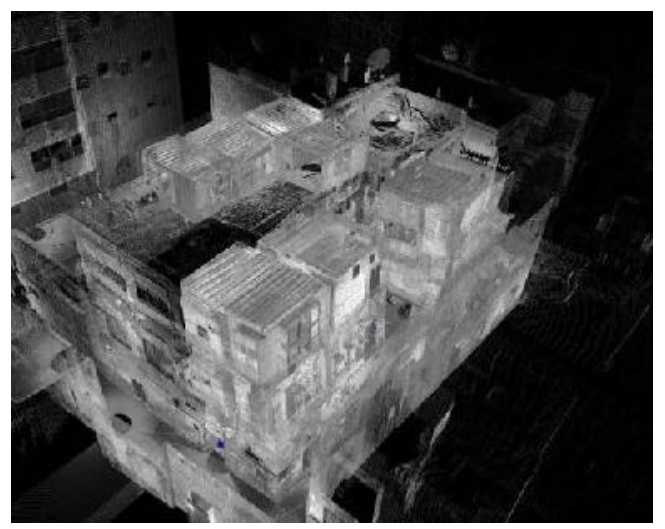

Fig. 7. Contour accurate horizontal and vertical sections derive from this $3 \mathrm{D}$ scan cloud. The classical 2D technical plans are inevitable for further use through architects and engineers involved into the upcoming rehabilitation projects for the house. The system comes from archaeology, as archaeologists depend much more on detailed surface information of building structures than architects and technicians in general. Nevertheless, for conservation and restoration of historic and traditional architecture this information is extremely useful for design decisions also. With courtesy of Irmengard Mayer and Gudrun Styhler-Aydin, Vienna University of Technology.

\subsection{The European Year of Monuments 1975 and the involvement of students}

The European Year of Monuments in 1975, a first political action initialized by the European Council in Strasbourg to save the European cultural heritage, certainly pushed the idea to use architectural students for systemic documentation and inventory in plan and short description. At that time, the built heritage of Europe was highly in danger because of modernization in great scale within the old city centers. Again, Strasbourg as the town, where Georg Dehio started his handbook series from, played an important role. From this German-French era also came Hans Koepf (1916-1994), who was my professor for history of architecture and building survey at Vienna University of Technology. He had studied at Stuttgart (Germany) and after being guest professor in Istanbul was evocated to Vienna in 1961.In 1963, he started the "initiative city-survey Austria"(Stadtbauaufnahme-Aktion Österreich) to document together with his students finally the street fronts and ground plans of historically valuable houses within 106 cities and towns of Austria and Southern Tyrol, Italy ${ }^{7}$. Private and public institutions like municipalities, provincial administrations or chambers of commerce and industry supported the initiative financially. Nevertheless, the costs were rather modest, as Koepf and his assistants worked without any extra payment besides the wages as university teachers. The students did not receive any

${ }^{7}$ Hassler, Bauforschung. Zur Rekonstruktion des Wissens, 2010, p. 162. 
money also, but travel expenses, photographic material, printing of the results of the documentation and exhibitions. Several publications from 1970 to $1975^{8}$ have been the output and finally a larger number of exhibitions within the documented cities from Vienna to Innsbruck, abroad in Dresden and Trieste, but also on scientific meetings and for celebrations. A vast echo in printed and broadcasted media paralleled the action and contributed essentially that nowadays nobody within Austria dares to demolish easily historic building stock. The most effective protection today is the public awareness, not law, as immediately once plans for investments touching cultural heritage show up initiatives of engaged citizens also show up, start questioning and produce public pressure. This very often is hard for investors and their architects but a very effective means of responsible bottom-up control under democratic rules of society. Koepf describes 1972 his undertaking himself as following9: When he started first as experiment in 1963 to document the facades along streets and places within some Austrian towns quickly two unexpected symptoms appeared. The students loved the initiative heavily and soon the politically responsible people like majors of towns started their interest for it. Therefore, already in 1965 a strategic planning was necessary. The professor travelled with his assistants systematically through the Austrian cities and towns and marked in site plans (scale 1:1000 meters) the valuable ensembles and photographed them strategically.

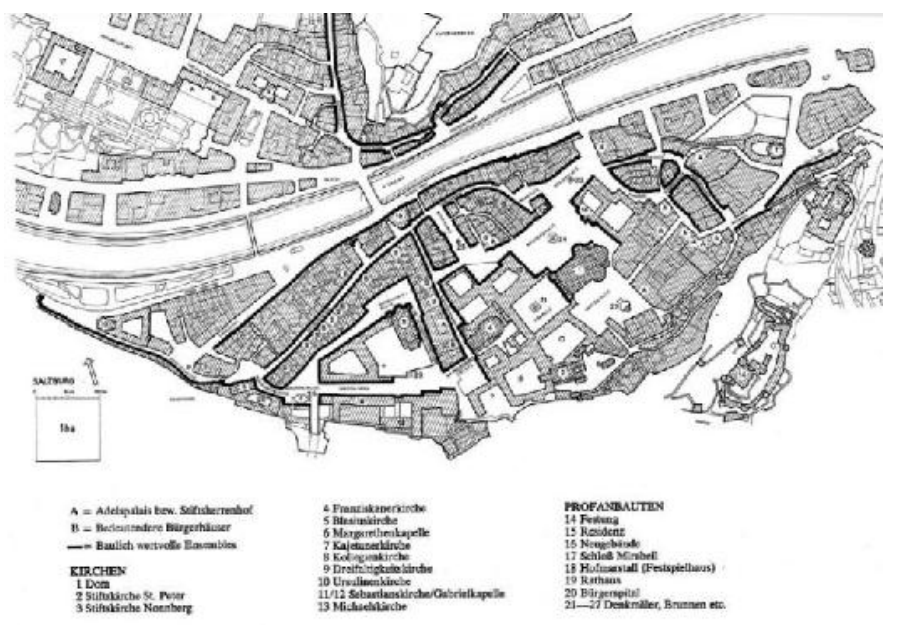

Fig. 8. The black line is marking the historically valuable building stock, Koepf and his team considered to be of particular importance for the historic ensemble of the old city center of Salzburg. Along the black line, the students of Koepf survey systematically the street elevations and drew technical plans in scale of those facades during the first phase of the initiative to document the historic towns of Austria. Hans Koepf, Stadtbauaufnahme in Österreich, Salzburg 1972, p.164

Of course, this journey helped to find and deepen personal contacts to the city administrations. A card index of "wanted" buildings, with their address and their photography, was the result. From this card index, the students had free choice for their work, mostly in small groups. Seminaries under supervision of an assistant and organized in bloc did take care of larger ensembles. The students did receive instructions in advance and through guidelines on paper. They went to the sites, measured the buildings and finished the drawings from their sketches and photography afterwards back at the university under

\footnotetext{
8 Hans Koepf, Stadtbauaufnahme in Österreich, Salzburg 1972, is summarizing the multi volume publications, documenting each province of Austria as well as some special historic towns like Salzburg and Krems.

9 See „Stadtbauaufnahmen im Rahmen des Architekturstudiums “, p. 16ff. in: Koepf, Stadtbaukunst Steiermark und Kärnten, 1974.
} 
control and review through the teaching crew. This led to standardized technical drawings in scale of each building with some guarantee for the scientific quality. Additionally to the hand drawn ink plans, the students made a report on the documented house containing their sketches as well as their pictures, but additionally with all the information on the history of the building and its physical condition at the time of the documentation - a solid base for further inventory. Again, the card index, now under "documented", referred to the result. If the quality of single students' work did not match with the criteria, the address went back to the "wanted" card index. At the beginning, the institute ordered only for very special objects a full set of plans with all ground plans, the necessary longitudinal and cross sections and all elevations. From all other houses only the street front and the ground plan documented its status. Later the system was changed to full sets for all objects - and the students could bring in their own suggestions for valuable houses of their home areas, as the action was such a success that the wanted card-index ran out after a while. Therewith, a big part of Austria's cultural heritage got its documentation systematically. What had started out as action to save the historic buildings at least in plan and picture before demolition, ended in a very fine collection of high quality plans and reports. Finally, the physical plan drawings ended within the archives of Federal Institute of Monument Protection (BDA).

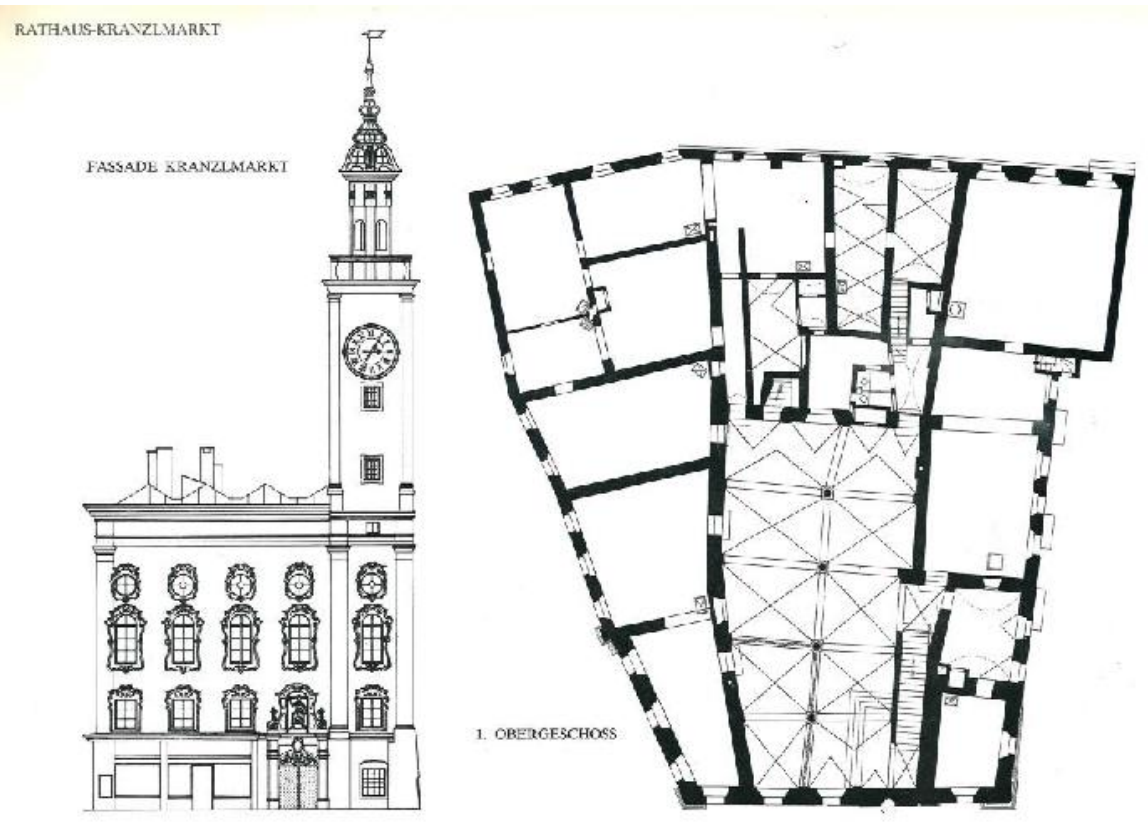

Fig. 9. Successively the elevation plans were compiled with the floor plans of the single objects like presented here; in later phases of the systemic city survey Austria all plans were drawn in scale 1:50, this is far more detailed than here in the early 70th of the 20th century. The building survey program for students of architecture was obligatory until changes within the curriculum after the turn of the centuries. Copy of a drawing from the archives of the Department for History of Architecture and Building Archaeology at Vienna University of Technology.

Recapitulating this huge undertaking of my teacher Hans Koepf, I still admire, besides the enormous quantity and the excellent quality of the documentation, his pedagogical approach for the architectural student. Early he confronted him/her already with historical building substance of highest artistically quality. This strengthened his sensibility for local and regional "idioms" to counter balance the more 
and more spreading, downgrading "all-world-architecture"10. Koepf not yet dared to speak of globalized dullness in architecture nearly forty year ago, but he meant this. "If you see today, how in the midst of the finest ensembles new buildings lacking any style are take place, it is absolutely necessary to study those local idioms to merge old and new into a sensible unit." (Wenn man heute sieht, wie sich besonders in kleineren Städten inmitten bester Ensembles völlig niveaulos Neubauten breitmachen, dann ist das Studium des besonderen Lokalidioms notwendig, um Alt- und Neusubstanz zu einer sinnvollen Einheit werden zu lassen.)

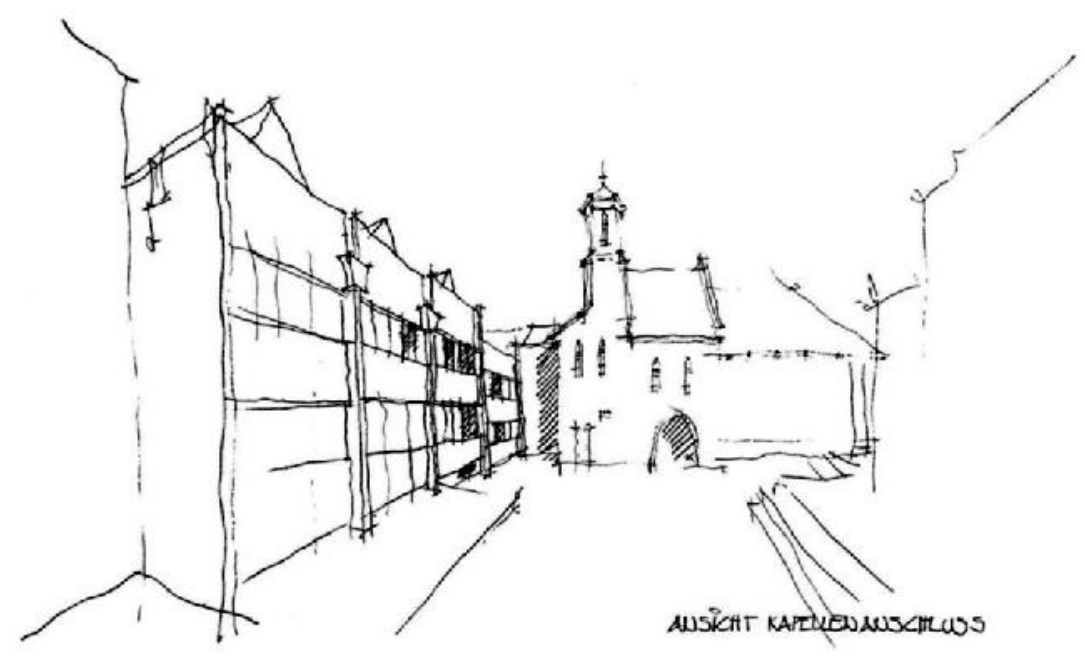

Stadtsanierung mit Rücksicht auf das Stadtbild: Krems/Stein, Neuplanung im Bereich Göttweigerhof-Kapelle. Seminar „Bauen in der Altstadt”, Institut für Baukunst TH Wien, Zeichner: G. Puchner

Fig. 10. "Rehabilitation of towns respecting the city scape": Suggestion for a new building in the area of Gottweigerhof at Krems. Students design from the seminary "Building within the old town" of the Department for History of Architecture and Building Archaeology at Vienna University of Technology.

Koepf added very clearly that this never means to imitate historic architecture, but should inspire sense for scale and proportion and for the right choice of material and structure. "Above all real urban qualities have to be promoted which today largely are missing what desolates the picture of the city. Finally, real urban qualities are real human ones." (Vor allem sollen echte urbane Qualitäten wieder gefördert werden, die heute weitgehend brachliegen und deren Fehlen zur Verödung des Stadtbildes führen. Letztlich sind echte urbane auch echte humane Qualitäten.)

\section{Conclusion}

Even Austria with its long tradition in systemic documentation and inventory has trouble in keeping up the speed necessary to publish current knowledge. This is easier for the short-speak of Dehio's handbook than for the detailed Topographies of Art. Therefore, the Dehio Handbooks do exist for all the provinces of Austria in an updated version. They reached a kind of publicity, for engaged lay people

10 „Stadtbauaufnahmen im Rahmen des Architekturstudiums“, p. 17. in: Koepf, Stadtbaukunst Steiermark und Kärnten, 1974 
in heritage agenda as well as for the expert in arguing pro or contra lists of monuments. On the other hand, enable the Art Topographies to publish extravagant research results on anyhow listed national monuments. The Federal Office of Monument Protection of Austria strictly supervise the quality of both series. Additionally, architectural guidebooks on the building stock of the $20^{\text {th }}$ century appear rather frequently and with enormous numbers of copies. They also operate on a high level of accuracy for the facts, but sometimes their judgment is superficially, to close to architectural journalism and with the problem of not yet enough distance in time. Nevertheless, they are a highly appreciated source of information by the advanced heritage tourist as well as the curious architect, as they compile addresses with architectural plans, otherwise not available for the public. For countries like Austria, both types of inventory books are available on a high level of completeness. They are still missing for young countries like Kosovo, but would be both, useful and necessary, to control the heavy building activities there. It is high time to start the systemic involvement of students of architecture to accelerate the documentation and inventory process as well as to build up awareness under the young professionals. The costs stay moderate, if you do this systemic inventory of the architectural heritage within the academic curriculum. By that way, you very probably archive objectivity, as the universities are standing outside of the profitable real estate market and/or political pressure on local level. The University of Business and Technology (UBT) with its large number of architectural students recently has started this systemic inventory of the architectural heritage of Kosovo and devoted herself to document under the international guidelines of ICOMOS (International Council of Monuments and Sites).

\section{References}

1. Achleitner, Friedrich: Österreichische Architektur im 20. Jahrhundert. Ein Führer in vier Bänden. Band III/1. Wien 1.-12. Bezirk, Salzburg-Wien 1990.

2. Bundesdenkmalamt (ed.): Dehio-Handbuch der Kunstdenkmäler Österreichs. Topographisches Denkmälerinventar. Wien II. bis IX. und XX. Bezirk, Wien 1993.

3. Dehio, Georg, Bezold, Georg von: Die Kirchliche Baukunst des Abendlandes. Historisch und systematisch dargestellt, Stuttgart 1888.

4. Frey, Dagobert: Die Denkmale des politischen Bezirkes Baden, Band XXVIII der Österreichischen Kunsttopographie, Wien 1924.

5. Ginhart, Karl: Dehio Handbuch der deutschen Kunstdenkmäler in der Ostmark. Erster Band. Wien und Niederdonau, Wien-Berlin 1941.

6. Hassler, Uta: Bauforschung. Zur Rekonstruktion des Wissens, Zürich 2010.

7. Huse, Norbert: Denkmalpflege. Deutsche Texte aus drei Jahrhunderten, München 2006.

8. Koepf, Hans: Stadtbaukunst in Österreich. Salzburg 1972.

9. Koepf, Hans: Stadtbaukunst in der Steiermark und in Kärnten, Band 4 der Schriftenreihe der Technischen Hochschule in Wien, Wien - New York 1974.

10. Lehne, Andreas: "Georg Dehio, Alois Riegl, Max Dvořák - a threshold in theory development", pp. 69-80 in: Conservation and Preservation. Interactions between Theory and Practice. In memoriam Alois Riegl (1858-1905), Proceedings of the International Conference of the ICOMOS International Scientific Committee for the Theory and Philosophy of Conservation and Restoration. 23-27 April 2008, Vienna 2008.

11. Leixner, Othmar: Einführung in die Architektur. Charakteristik der Baustile, der Hauptwerke der Baukunst und Ihrer Meister, die Grundzüge des Städtebaues und des Denkmalschutzes, Wien und Leipzig 1919.

12. Gerhard A. Stadler: Das Industrielle Erbe Niederösterreichs. Geschichte-Technik-Architektur, Wien-Köln-Weimar 2006.

13. Manfred Wehdorn, Ute Georgeacopol-Winischhofer: Baudenkmäler der Technik und Industrie in Österreich. Band 1. Niederösterreich. Burgenland, Wien-Köln-Graz 1984. 